\title{
Protecting culturally significant areas through watershed planning in Clayoquot Sound
}

\author{
by Holly Spiro Mabee ${ }^{1}$ and George Hoberg ${ }^{2}$
}

\begin{abstract}
Through the Scientific Panel Planning process, First Nations in Clayoquot Sound have had the opportunity to identify and map their culturally significant areas in order to ensure their protection in forest management activities. In this study, individuals involved in forest management from government, industry, and First Nations sectors were interviewed to measure the success of this undertaking. It was found that despite many challenges, First Nations cultural values mapping in Clayoquot Sound has been beneficial for all parties involved in forest management. Key benefits has been an improvement in consultation effectiveness for all parties, and increased confidence among First Nations that their values are being protected. Funding should be provided to allow this process to be completed for the remainder of the landbase.
\end{abstract}

Key words: First Nations, cultural values mapping, British Columbia, Nuu-chah-nulth

Par l'entremise du processus de Planification du groupe scientifique, les Premières Nations de Clayoquot Sound ont eu la possibilité d'identifier et de cartographier les territoires ayant une valeur culturelle significative de façon à assurer leur protection lors d'activités d'aménagement forestier. Au cours de cette étude, les individus impliqués dans l'aménagement forestier en provenance du gouvernement, de l'industrie et des Premières Nations ont été interviewés afin de mesurer le succès de ce projet. On a relevé que malgré les nombreux défis, la cartographie des valeurs culturelles des Premières Nations de Clayoquot Sound a été bénéfique pour toutes les parties impliquées en aménagement forestier. Les principaux bénéfices ont été une amélioration de l'efficacité des consultations pour toutes les parties et une confiance accrue parmi les Premières Nations que leurs valeurs étaient protégées. Des fonds devraient être accordés pour permettre au processus d'être entrepris sur le reste du territoire.

Mots-clés: Premières Nations, cartographie des valeurs culturelles, Colombie-Britannique, Nuu-chah-nulth

\section{Introduction}

Over a decade has passed since the legendary 1993 protests against the logging industry in Clayoquot Sound. In 1995, the government of British Columbia adopted and committed to implement the recommendations of the Scientific Panel for Sustainable Forest Practices in Clayoquot Sound, created as part of the solution to the conflict. These recommendations promised to bring world class forest practices to the region, including the incorporation and protection of First Nations values in forestry. ${ }^{3}$

This study examines what progress has been made with the implementation of the Scientific Panel recommendations on the protection of First Nations culturally significant areas. This paper attempts to decipher the complex and wide range of factors that challenge or facilitate their implementation. The research was accomplished through qualitative analysis of interviews with individuals in each sector involved in implementation: the forest industry, the government, and the First Nations.

\section{Description of the case}

Clayoquot Sound consists of 350000 hectares of temperate rainforest, ocean inlets, and wind swept beaches on the west coast of Vancouver Island in British Columbia. It is known as one of the last remaining areas of relatively undisturbed, old

\footnotetext{
${ }^{1}$ Research Associate in the Department of Forest Resources Management in the Faculty of Forestry at the University of British Columbia. E-mail: hspiro@interchange.ubc.ca. The author to whom correspondence should be sent.

${ }^{2}$ Professor and Head of the Department of Forest Resources Management in the Faculty of Forestry at the University of British Columbia.

${ }^{3}$ The Scientific Panel's Report 3, "First Nations Perspectives Relating to Forest Practices Standards in Clayoquot Sound," also addresses other issues, including First Nations participation in forestry through co-management, and the integration of traditional ecological knowledge and science in forest management, but this research is focused on the recommendations on the protection of culturally significant areas.
}

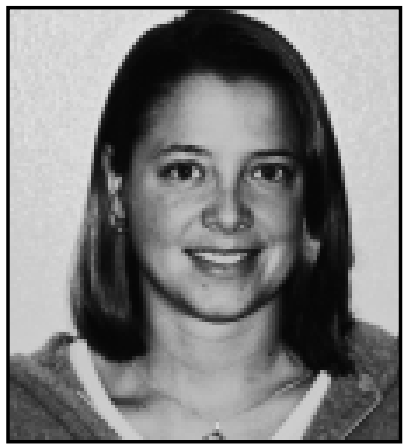

Holly Spiro Mabee

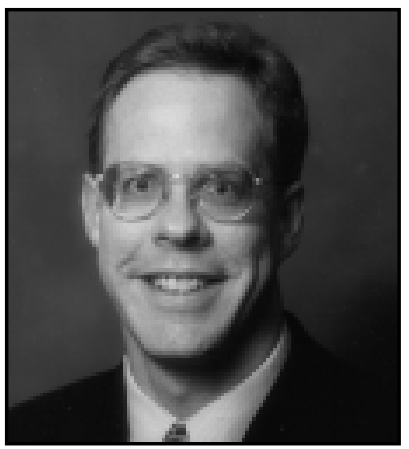

George Hoberg growth forest on the island, and has been home to the Nuu-chahnulth First Nations people for thousands of years (CSSP 1995b, Ministry of Forests 2000).

The abundance of natural resources and wilderness values in the region has lead to long-standing conflicts over appropriate land use in the Sound (Ministry of Forests 2000). In the mid 1980 s through to the early 1990 s, these conflicts came to a head and became known across the province, the nation, and beyond as "the War in the Woods." This conflict saw environmental non-government organizations (ENGOs) and First Nations set up blockades on logging roads, refusing to allow forest companies to proceed with their harvesting operations in what were the largest displays of civil disobedience in the province's history (Darling 1994). Part of the government's solution to the crisis was the formation of the Clayoquot Sound Scientific Panel (CSSP) in 1993.

The CSSP was composed of scientists and First Nations representatives. The panel was charged with developing recommendations to create "world-class forest practices" in Clayoquot 
Sound (Iisaak Forest Resources 2002, Ministry of Forests 2000). The CSSP produced five reports that included more than 120 recommendations, among which were calls for a more detailed planning and monitoring process, reforms to specific forest practices, and recognition for the importance of First Nations values to forest management. On July 6, 1995, the government of B.C. accepted the panel's recommendations by cabinet decree, and the Ministry of Forests committed to their implementation (Ministry of Forests 1995).

The Scientific Panel Recommendations called for watershed unit plans that will set aside a reserve network to protect ecological, recreational, and cultural values on the landscape. As long as it is carried out in a manner consistent with the panel's recommendations, logging will be permitted on the remaining landbase, termed the "Harvestable Area."

The Scientific Panel called for three levels of plans to be created: sub-regional plans, watershed plans and site level plans. This study is focused on watershed plans since they were given top priority by the Panel. A multi-sectoral planning committee was formed that divided the land base into 14 watershed planning units.

The first three draft watershed plans were completed and underwent public review from July to October 2002 and then were passed to the Parties to the Interim Measures Extension Agreement (IMEA) for approval (the Parties referred to are the Provincial government and the Central Region Chiefs of the Nuu-chah-nulth First Nations) ${ }^{4}$. These plans are for the Cypre, Bedingfield, and Flores Island planning units, which are all in the traditional territory of the Ahousaht First Nation, the largest of the 14 Nuu-chah-nulth tribes on Vancouver Island. No official watershed plans are in place as yet, but when approved it was intended that these plans, or some of their objectives, would be legislated as higher level plans under the Forest Practices Code Act of British Columbia. The watershed plans each contain a set of overlaid maps containing reserve networks for the various values requiring protection according to the Panel's recommendations. This study focuses on the layer designed to protect First Nations culturally significant areas.

\section{Rationale and research questions}

It has been suggested that a framework similar to the CSSP recommendations should be adopted elsewhere on the B.C. Coast. However, there has been little analysis of what the Scientific Panel Recommendations have actually achieved. Although there has been some partisan analysis of the recommendations on ecosystem management (notably by Friends of Clayoquot Sound in 1998), there has been no similar analysis for the recommendations on First Nations perspectives.

This study will answer the following questions: How have the recommendations on the protection of cultural areas been implemented? What have been the impacts of their imple-

\footnotetext{
${ }^{4}$ The Interim Measures Extension Agreement is a pre-treaty agreement between the First Nations and the Province that allows for co-management of resources via the Clayoquot Sound Central Region Board (CRB) as well as opportunities for economic development in the First Nations communities. The first Interim Measures Agreement was signed in 1994. The agreement was extended in 1996 and again in 2000. The current agreement is in effect until 2005 or until a treaty is signed, whichever comes first (Province of British Columbia and the Ha' wiih of the Tla-o-qui-aht First Nations, the Ahousaht First Nation, the Hesquiaht First Nation, the Toquaht First Nation, and the Ucluelet First Nation 1994, 1996 and 2000).
}

mentation? And finally, what factors have contributed to the challenges and successes associated with their implementation?

\section{Review of the Literature}

Since the 1970s, mapping of culturally significant areas (CSAs), often referred to as Traditional Land Use and Occupancy Studies, have been carried out with increasing frequency by First Nations communities in Canada and indigenous peoples around the world (Horvath et al. 2001). Such studies involve collecting, documenting and mapping data about traditional and contemporary land use, by conducting interviews with elders and other users (Horvath et al. 2001). The process has been described as the geography of oral tradition or the mapping of cultural and resource geography (Tobias 2000).

CSA maps have a multitude of functions for First Nations in addition to their value for forest management and planning. They can be used in land claims, treaty negotiations, education curricula, and community planning (Tobias 2000). CSA maps are most commonly developed, however, as an information tool that can assist First Nations, industry and government in resource development decision-making (Horvath et al. 2001).

In Canada and all its provinces, the government is required to ensure that it does not unjustifiably infringe on constitutionally protected Aboriginal and Treaty rights (Constitution Act 1982, Sec, 35.1). They are legally bound to consult with First Nations prior to the development of forestry operations in any First Nations territory. If there is not adequate information on aboriginal rights in the area, adequate consultation cannot occur (Horvath et al. 2001). Thus, CSA mapping is a necessary step in allowing government to fulfill its fiduciary obligation toward First Nations people. ${ }^{5}$

Several conditions that can improve the success of CSA mapping projects have been highlighted in the literature. Studies have shown that successful projects are those that are communitydriven and participatory. Projects that have been initiated and led by outsiders do not have much benefit to the community (Tobias 2000, Horvath et al. 2001, McGregor 2002). First Nations communities should have control over designing the process for CSA mapping as well as the kind of information they would like to display and how much detail will be released (Gardner 2001, Horvath et al. 2001, McGregor 2002). This study will demonstrate how these factors apply in the Clayoquot Sound case.

The literature also presents several issues regarding the nature of CSAs that can often create difficulty for ensuring their protection. Challenges that commonly arise are listed below, and will be explained in more detail as they relate to the Clayoquot Sound case in the results and discussion.

One common challenge is confidentiality. Because of their personal and private nature, many sites are confidential to individuals or families. People often do not want the locations and uses of these sites to be common knowledge even within the First Nation, let alone among industry and government sectors (CSSP 1995a, Tobias 2000).

A second common challenge is that for many First Nations people, the whole landscape and its component parts, both biotic and abiotic, are sacred. Because all things are sacred, all places

\footnotetext{
${ }^{5}$ When the federal government took on First Nations peoples as "wards of the state" in Canada's early colonial history, it took on a "trust-like" fiduciary responsibility to act in their best interests.
} 


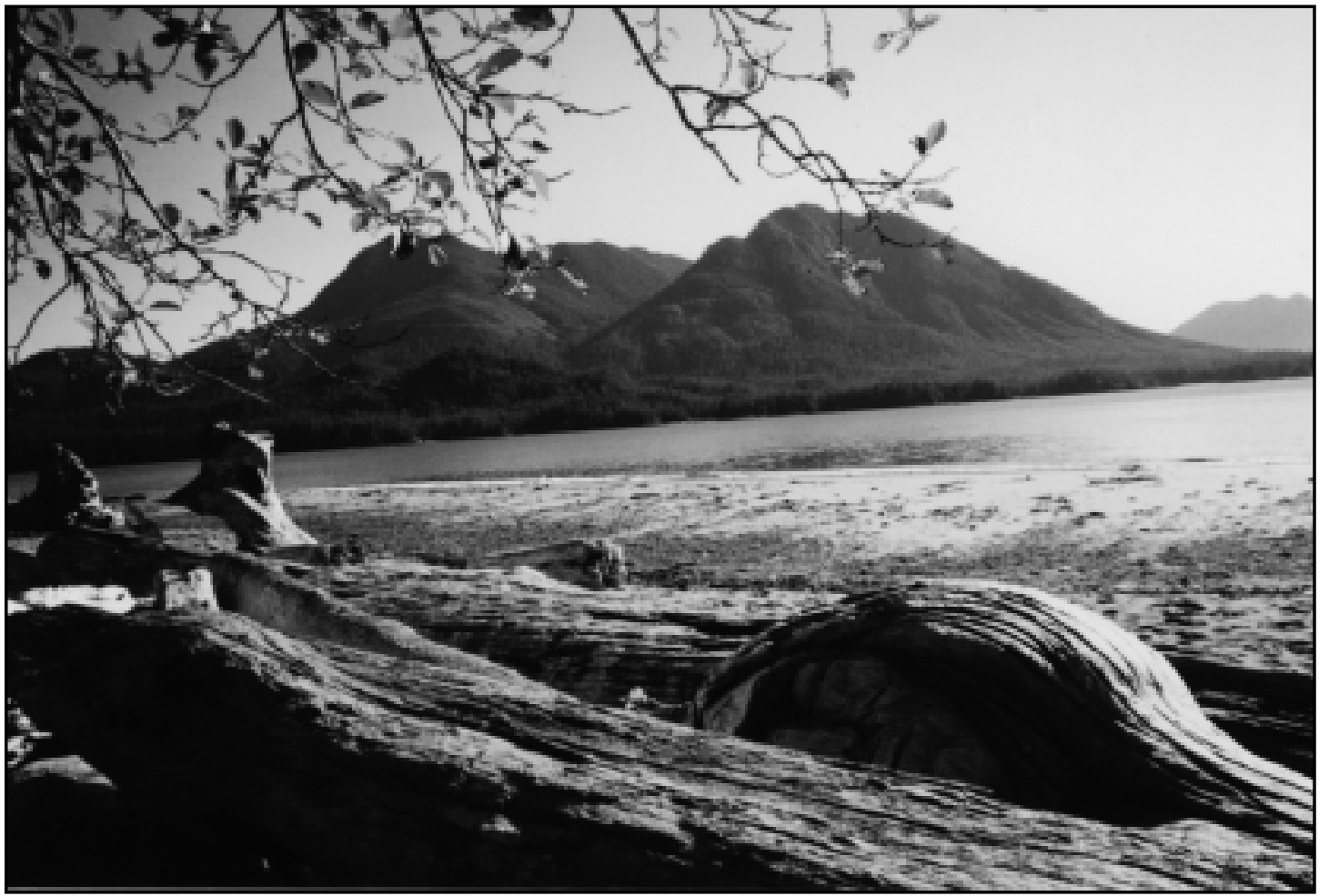

are sacred (Erasmus 1989, Oakes et al. 1998). This is challenging when tradeoffs must be made between protecting the land for cultural and spiritual reasons, and getting involved in industrial forest management for economic reasons (Booth 1998, Horvath et al. 2001).

A further complication is that sacred sites generally have no physical evidence. First Nations sacred sites are in people's minds and oral histories, and as such they are questioned by the western tradition that relies on writing and physical evidence (Oakes et al. 1998, Tobias 2000). This lack of visible signs of sacred sites highlights the importance of CSA mapping, in order that developers can be made aware of the presence of such sites, so as not to unwittingly damage them.

Further to this, CSA maps usually have blank space between the sites, and the interpretation of this blankness by forest licensees can be problematic. Corporations and agencies may carry on with business as usual on areas for which no data are mapped; however, the blank space might be critical to the survival of a culture. For example, there may be specific locations where ceremonial acts take place, but the surrounding area must remain intact for the entire ceremony to retain its cultural value (Tobias 2000 , Toupal et. al. 2001).

A practical challenge is that culture and uses of land are evolving and hence CSAs are changing over time. Thus, CSA mapping must be an ongoing process (Erasmus 1989, Tobias 2000, Hovarth et al. 2001).

This brings up the challenge of ground-truthing. Ideally, once people have marked their important sites on a map, they are taken to the field and the exact location of the site is determined using GPS (Global Positioning System) (Tobias 2000, Horvath et al. 2001). Although ground-truthing is time-consuming and expensive, it is important to ensure that sites will be not be dam- aged by development due to inaccurate maps.

A final challenge that is frequently discussed in the literature relates to the difference in worldview with regards to the relationship of people and nature. The western view of humans being in dominion over nature, is the basis for the concept of zoning and carving off "protected areas" and excluding them from human use, in the name of conservation and "wilderness preservation." In First Nations worldviews, people are an integral part of nature, and the concept of wilderness protected from people has no meaning (Erasmus 1989, Oakes et al. 1998, Gardner 2001, Toupal et al. 2001).

\section{The Scientific Panel recommendations on culturally significant areas}

As the Scientific Panel explained in Report 3, certain culturally significant sites are protected as cultural heritage resources under the provincial Heritage Conservation Act However, the Act only affords legal protection to "archaeological sites" and "historic sites," both of which require physical or written evidence. This does not encompass the full range of sites that are culturally important for First Nations. Many culturally important sites such as sacred sites have no physical or written evidence, and thus remain without legal protection. The Scientific Panel recommended that sites communicated by oral traditions alone, as well as those with physical and written evidence, should be protected (CSSP 1995a).

The Scientific Panel recommended that Nuu-chah-nulth cultural sites be protected from logging in Clayoquot Sound; this recommendation includes medicinal plant-gathering sites, food-harvesting sites, and ceremonial sites, to name a few. They recommended that First Nations be given the opportunity to identify, locate, and evaluate the culturally significant areas that lie within their territory before any forestry planning 
occurs. They further recommend that First Nations identify appropriate methods for protection of these sites, according to the area and use (CSSP 1995a).

This study was designed to determine the extent to which these recommendations on protecting CSAs are being implemented for forest management in Clayoquot Sound.

\section{Methods}

Semi-standardized interviews using open-ended questions were conducted in Clayoquot Sound from September to November of 2002. Interviews lasted from 20 minutes to 90 minutes depending on the subject. The purposive sampling method was used, whereby interviewees were non-randomly selected from among those who met the sampling criteria. Subjects had either been directly involved with implementing the Scientific Panel recommendations, or had been otherwise involved in forest management in the region since 1995.

The snowball method (Babbie 2001) was used to broaden the initial list of possible participants provided by key contacts from each group. At the end of each interview, the subject was asked to identify other possible subjects in their group. This guarded against potential biases of initial key contacts regarding who should be interviewed from their organization or group. Following the purposive sampling technique, the number of people required for interviews in each category was not predetermined; rather, individuals were interviewed until it was found that the return of new significant information or perspectives for each successive interview had disappeared.

The First Nations sector includes the three First Nations in Clayoquot Sound: the Ahousaht Nation, the Hesquiaht Nation, and the Tla-o-qui-aht Nation. The government sector includes the Ministry of Forests and the Ministry of Sustainable Resources Management. The Industry sector includes the two major forest licensees: International Forest Products (Interfor) and Iisaak Forest Resources (Iisaak).

Interviews were recorded on audiotape and transcribed. Transcriptions were analyzed using ATLAS/ti, qualitative data analysis software designed around the grounded-theory method (Muhr 1997). Grounded theory, which was developed by Glaser and Strauss in 1967, involves the interplay of experience, induction, and deduction. Hypotheses and theories about the data develop as coding proceeds, and are tested by coding further data (Strauss 1987, Babbie 2001).

Transcripts were coded according to themes drawn from the Scientific Panel recommendations themselves. In accordance with the research questions, other themes were developed from a thorough review of the policy implementation literature. Specifically, these themes related to outputs of implementing agencies, meaning what actions these agencies have taken to implement the recommendations, perceived impacts of these actions on target groups (those whose behaviour the recommendations are intended to affect), and challenges and successes associated with implementation activities. See Spiro 2003, Section 2.3 for a detailed explanation of this framework.

For each theme, all of the quotations that had been coded into that category were reviewed. In conducting this exercise, it was intended that trends and differences in perspectives among interviewees from a given sector would be identified, as would contrasts and comparisons of perspectives between interviewees from different sectors. This allowed a summary to be constructed of the various perspectives of interviewees on a particular theme,
Table 1. Number of interviewees by sector

\begin{tabular}{lc}
\hline Sector & Number of Interviewees \\
\hline First Nations & 16 \\
Government & 6 \\
Industry & 8 \\
Total & 30 \\
\hline
\end{tabular}

in a way that recognized the spectrum of variation of responses of different interviewees. This also addressed the relevant contrasts while allowing generalizations to be made where interviewees' opinions on a theme were consistent. Representative quotations were selected and included in the results to demonstrate interviewees' perspectives on each theme.

\section{Results and Discussion \\ Implementation of the recommendations \\ Government implementation efforts}

Government's most important output in this area is funding allocation for watershed planning activities, including the cultural layers that the First Nations are producing. Several interviewees said that the government has spent approximately $\$ 10$ million on inventories in Clayoquot Sound for landscape level (1:20 000) inventory work, including both archaeological and ecological inventories.

\section{Industry implementation efforts}

Forest licensees play a critical role in ensuring the protection of First Nations cultural values, as they are the ones operating and affecting the forest on the ground. Industry has been heeding the recommendations and protecting a much broader definition of cultural values than those with legal protection. ${ }^{6}$ This is accomplished primarily through consultation with the First Nation in whose territory they plan to operate.

The recommendations do not define how consultation should be done. Licensees are flexible and will consult with each First Nation in the way that they prefer. This flexibility is exemplified in the following quote from an Interfor interviewee:

"We work within any framework that the band decides. And it changes. It evolves. People change, band administration changes... basically, I can't tell the band how to organize, so I submit plans and I respectfully request comment back."

Interviewees emphasized that consultation involves constant contact and interaction with the First Nations in whose territories they are operating, as this quote from an Iisaak interviewee demonstrates:

“...we continually go back to them as that area has been, like if they said yes, you can go in there but not at this particular spot, well every time we go into a new phase we show them the map and we show them the way the block is configured-you know and they get the final say. If they decide at the end of it that they've changed their mind and they don't want us in there then we don't go in there... So

\footnotetext{
${ }^{6}$ Certain cultural values have legal protection through the Heritage Conservation Act, and/ or through the IMEA. The IMEA affords legal protection to Culturally Modified Trees (CMTs) by requiring industry to get written permission from the First Nations in whose territory they are operating before removing or damaging a CMT.
} 
the initial yes-does not mean yes throughout the process, it means yes, you can proceed to the next phase."

Both licensees note the importance of consulting as early as possible, to avoid loss of resources (time and money) from planning in an area that turns out not to be operational from a First Nations perspective. Early consultation is also helpful in the preparation of forest development plans. If they know about First Nations culturally important areas up front, they can maximize the overlap of old growth and other reserves with the areas that need protection for First Nations values, allowing them to maximize the remaining harvestable area.

\section{First Nations implementation efforts: The CSA mapping process}

First Nations main role was developing their cultural layers for the watershed reserve plans. Each First Nation developed its own process for protecting its cultural values through these plans. The main process is similar, but the outcome is different for each First Nation. Note that the only completed draft watershed plans at the time of this study were in Ahousaht's territory; thus, this section is largely concentrated on Ahousaht's planning process and products.

Ahousaht set up a process to interview all members on areas that were culturally important to them. The interviewers assured members up front through a signed agreement that any information they contributed would remain confidential and would only be available to Ahousaht members dealing with resource management decision-making; it would not be available to government or industry, or to the public.

Ahousaht also held two open workshops where members could come and give additional input, and help decide how this information would be collated for use in the watershed plans. In these workshops, they decided that they did not want their cultural areas to be strict reserves, in that they would not necessarily be no-logging zones. They decided on the term, "culturally significant areas" (CSAs), and these areas were classed as special management zones. The level and type of logging activity allowed in the CSAs will be determined through consultation between the proponent and Ahousaht (Clayoquot Sound Technical Planning Committee 2002).

Ahousaht, for the purposes of its own confidential maps, divided CSAs into red, yellow and green zones. Red zones are no logging zones. Yellow zones are areas where if there is proposed logging activity, the family or individual to whom that area is important must be consulted in terms of how their values in that area need to be protected. Green zones are areas where Chief and Council have been cleared by the members to whom that area belongs, to make decisions on how that area will be protected where there is proposed logging activity, without the need to consult further with individual or family users. The red, yellow and green zones were amalgamated into red zones for the maps of the cultural layers of the draft watershed reserve plans, which are publicly available. Proponents are still required to consult with Ahousaht in the white areas of the maps, but they can expect a longer consultation process in the red zones.

The Hesquiaht Nation also interviewed its members to get the information for its cultural layers. The draft watershed plan for the Hesquiaht planning unit had not been finalized at the time of this study. Hesquiaht hired a consultant to interpret the impact the Scientific Panel recommendations would have in its territory, in terms of where reserves would be for other values. Hesquiaht has used the maps from this interpretation in developing the maps for their cultural layer.

The Tla-o-qui-aht gathered information on culturally important areas from their members through an interview process. Watershed plans for planning units in its territory had not been released at the time of this study. The Tla-o-qui-aht decided to use reserves, which will be strict no logging zones, as are the reserves for ecological values in the watershed plans. ${ }^{7}$

All three First Nations mentioned that their cultural layers are open to new information that arises over time; they do not feel that they will ever have collected all the information that all their members hold on cultural values, and hence the maps must be open to amendment as necessary.

First Nations will play the key role in monitoring their CSAs/cultural reserves and ensuring that licensees are not damaging them. Even though they have liaisons working with the licensees who will be monitoring for cultural values at the site level during operations, they may also need some impartial monitoring by members who are not on the staff of the companies, who can carry out post-harvest monitoring in order to determine the impacts on their cultural values.

\section{Impacts of the recommendations}

\section{CSA maps enhance protection}

With some exceptions, First Nations interviewees were generally satisfied that once the watershed plans including their cultural layers are in place, if they are used properly by their own resource managers and other people involved in consultation, then their values should be protected.

Many First Nations interviewees felt that in general their cultural areas are being protected quite well already through the work of the liaisons and the First Nations employees that are involved in operations. Although some say that there is a long way to go, they recognize that things are much better than they used to be. Ahousaht and Hesquiaht liaisons said that licensees cooperate on features they recommend for protection and exclude them from cutblocks.

Some First Nations interviewees were concerned, however, that although physical values like culturally modified trees (CMTs) and medicinal plants are being addressed, spiritual values are not adequately protected. This is shown in the following quote from an Ahousaht member:

“...Catface Mountain where- that man went up there...he used to sing a song up there... and people down here would hear it...when he was up there. And that in itself has value and... and they don't recognize that part."

Interviewees from all other sectors also alluded to the difficulty of protecting more ubiquitous values such as medicinal plants and spiritual values on the landscape, as opposed to prominent physical attributes such as CMTs. The cultural layers for the watershed plans should improve this because people were able to include these kinds of values on the maps and the liaisons and resource managers will have access to this information. In that way, they should be able to ensure that every-

${ }^{7}$ It will be interesting to see how the different systems each First Nation has developed for protection of its cultural areas through the watershed plans will affect operations in its territories, if and when the watershed plans become higher level plans. It will be a few years before any such study could be conducted. 
one's physical and spiritual values are protected, including some that they may not have been aware of before these inventories were available.

\section{CSA maps improve consultation}

The completion of the cultural layers for the watershed plans will have a significant impact on improving the efficiency and effectiveness of consultation. The maps will make the process of consultation and responding to forest development plans quicker and more thorough for First Nations.

Since different families use different areas, and this knowledge is not shared between families, the consultation process was often slow and complicated in the past, and the liaison or resource manager may not have known who to contact regarding a particular area. With the information available in the cultural layers, they will be able to ensure the protection of areas of importance to all families who volunteered information, without having to track people down for input for every new application.

From the interviews, it was very clear that all three First Nations think cultural areas mapping is very important and all need money to complete it for the rest of their territory. This is shown in the following quote from an Ahousaht member:

\begin{abstract}
"We need to know who to consult internally about the values-how can we if we don't have that information from family groups....we've actually had it used-some of the information that was collected-we could contact the people for where they were planning on logging-we were able to contact them directly."
\end{abstract}

Government representatives all see the tremendous impact that the cultural layers of the watershed plans will have, in allowing the First Nations to more efficiently and effectively respond to development plans and other resource development activities when required.

“...that whole planning process within Ahousaht in these first three plans has been crucially important to ensure that down the way, when any forest activities take place, there's already this base of understanding of what's out there to protect. And you don't leave Ahousaht having to scramble to try to figure it out on the go. That might be too extreme a characterization but you know I think that the base of planning is going to make for an improved and more, you know less stressful kind of response in a community like Ahousaht."

Although government and industry both feel that the watershed plans in general are critical for being able to plan their operations, some interviewees working on the operations side were disappointed that they didn't get more certainty in the CSA maps from Ahousaht. They were hoping for smaller reserved areas, rather than the large special management area of between $30 \%$ and $68 \%$ in each watershed unit that is covered by CSAs. They say that having such large contiguous portions of watersheds specified as CSAs does not help them much in terms of their operational planning.

Some industry interviewees felt that the existence of the cultural layers in the watershed plans will not change the way they do business, because they are already doing detailed consultation at the site level for all their operations. The CSA maps do not preclude the need for consultation on the entire land base, whether operations are planned for a culturally significant area or not. However they do recognize that the maps will be valuable to Ahousaht for their own purposes in enhancing their capacity for effective consultation.

\section{Factors affecting implementation}

There are many factors that affect whether the recommendations are being implemented or not, and why those implementation efforts have been effective or not. The key factors are presented below. A challenge is a factor that makes successful implementation more difficult. A facilitator is a factor that makes successful implementation easier. This framework for implementation analysis was developed in Holly Spiro's masters' thesis (Spiro 2003).

\section{Challenges \\ Confidentiality}

According to Nuu-chah-nulth tradition, information on CSAs is not shared between families, and especially not outside the nation (tribe). This creates an obvious challenge for protecting CSAs, since families and individuals do not want people to know where their CSAs are.

Along with the spiritual and traditional reasons for confidentiality of CSAs, there are more pragmatic reasons. Interviewees were concerned about theft of cultural artefacts. In addition, if locations of sacred sites become public knowledge, First Nations worry that tourism operators may want to include sacred sites in their tours. First Nations have experienced theft of valuable articles from burial sites in the past when the locations of such sites have been disclosed to outsiders.

The following comment from a Hesquiaht interviewee demonstrates this reluctance to share CSA information with forest licensees:

“... if there is an area that isn't covered in that-I may not even say anything at that stage and here's why. Just because it's white and not protected, it doesn't mean that's where a forest company's gonna go and log. So, and then it comes into the next stage of FDP. I look at a FDP, and I look at where they plan on having forest activity. Now if there's an area that is important to Hesquiaht, and they planned on logging, then I may say something. Depending on what stage it's at. If it's at a-for your information, then I probably wouldn't say anything. If it was at a proposed stage, then, this is where I would say-Ok, I don't want you to log that, I don't want you to do that block. Then, you know they have to take that into consideration. Basically all I would say is that it's culturally important to Hesquiaht. So, it all goes back to that...I'm not gonna tell someone what's important to me, if they're not gonna do anything with it. Why tell somebody when you don't have to-right?'

It can be problematic when First Nations do not want to share information on the locations of their CSAs unless companies already have a plan to develop in that area. This is unfortunate because at that stage, if the company has to change the plan, it is a loss of resources to them. It would be better if the com- 
pany knew, at least roughly, the areas not to go into before doing any plans.

Industry interviewees stated that they protect any site or value that the First Nations liaisons tell them should be protected. They do not require the First Nations to disclose information on why that site is important, or what the value is that they are protecting. This helps to alleviate the challenges related to confidentiality and family ownership of cultural sites, which will be discussed later. Industry's flexibility in this area is demonstrated in the following quote:

"...we go to the hereditary Chief and the Chief and Council and ask them if there are any concerns about us operating in that area. And they may say, you know it's OK in this particular area and then draw a circle on the map and say I'd prefer that you don't go there. And they don't have to tell us which one of these things (referring to the list of types of cultural values from Report 3 ) that is. So it could be anything. It could be these things or it could actually be something else. So that way, their cultural history is protected and we just know that we don't go there."

Trade offs between economic development and protecting cultural areas: Complications of family ownership

According to the Nuu-chah-nulth's traditional land and resource management systems, different families or individuals have use rights and stewardship responsibilities for different sites for extracting resources such as medicinal plants, or food for subsistence, or wood or bark for personal use from different areas. The reason that family ownership creates a challenge for implementing the recommendations on protecting CSAs, apart from the confidentiality of this information among families, is that different families will likely want different levels of protection for different areas. It makes it hard to establish what areas need to be protected, in terms of which areas will be no-logging zones, and what sites just need buffers, or other special management considerations. For each family, a different value and area may be most important and they may want it to be a no-logging zone.

The elected government of each First Nation has economic development for the tribe as one of its goals. It must make decisions that it feels are in the best interests of the tribe, in terms of the balance between the need for economic development, and the need for protection of cultural values, but these decisions will likely not satisfy all families. Some families' areas might be encroached on by forestry, in the name of economic development. Where First Nations want to get benefits from logging in their territory, such as employment, and profits in the case of Iisaak and their own tenures, there will be a need for collective decision-making regarding trade-offs in this regard.

\section{Differences in worldview: Relationship between people and the environment}

The major differences between First Nations worldviews and the western worldview — on which planning for forest management in B.C. is based - create additional challenges for protecting CSAs. The most important difference in worldviews, with respect to protecting CSAs, is the different positions on how people relate to the ecosystem.

A government interviewee acknowledges this difference in the following quote: “...they (First Nations) consider themselves part of their ecosystem I think in a way that perhaps the colonized culture hasn't. We see ourselves as perhaps more in dominion over nature than First Nations do."

This difference in worldviews is the fundamental cause of the difference in opinion between First Nations and non-First Nations regarding parks and protected areas. It is evident in Ahousaht's approach to protecting CSAs in the watershed unit plans; this Nation has abandoned strict reserves that do not allow people to interact with the land in favour of special management zones. Ahousaht's reasons for its approach to protecting its cultural areas are explained in the following quote:

"One of the sticky things in that was the interpretation of reserves-that they were going to be a no-go zone at all. As Ahousaht we felt that if we close off these areasthat would prevent not only Mamulthne but Ahousaht as well from going in there. And we felt that-not only for economics or what have you that we didn't want to shut these places down to prevent even us from going into there-so that was one of the sticky points in that area." 8

\section{Differences in worldview: The whole landscape is culturally significant}

If you define CSAs broadly, as some First Nations interviewees did, it is difficult to protect them in the context of the watershed plans. Some interviewees stated that the whole landscape is significant to them, due to stories their grandparents used to tell them about sacred sites, or places where wars took place, or beaches where people prepared for whaling, and so on.

The following comment by an Ahousaht member displays this sentiment:

"Every area on these maps are significant-they mean lots to me. They've done research and found CMTs and canoes on the land... There's medicine there-used to be more 100-150 years back. We fought for the rivers in the territories. Our great-great grandfathers."

It is hard to protect these kinds of values in the western context of land use planning, which is designed around protecting pieces of the landscape. However, if these values can remain intact through the application of the right kind of selective, lowimpact logging, they can be protected. Part of the difficulty is that different people have different opinions on what constitutes sufficient protection of these areas.

Overlap of CSAs and other reserve layers: Access vs. protection

The above difference in worldview may create a challenge in implementing the watershed unit plans, if and when they are adopted as higher level plans under the Forest Practices Code. In the draft plans, there is much overlap between CSAs and reserves for other values. Since these other Scientific Panel reserves, i.e., for hydroriparian values or old growth values or ecosystem representation, are considered to be strict no-logging zones, this might create a problem.

\footnotetext{
8"Mamulthne" is the Ahousaht word for white people, or non-First Nations people. An interviewee told me that it means "people who live on the water," and was used originally used to describe the first European explorers, who lived on their ships.
} 
Future First Nations access to their CSAs may be restricted where they overlap with these other reserves, hindering their ability to gather resources for ceremonial or subsistence activities.

There are different perspectives on this. Many First Nations interviewees had not even considered this issue, because they don't see their activities on the land as damaging to any other values, so they would not even think of being excluded. This is shown in the following quotes from interviewees from Ahousaht and Hesquiaht:

"For cultural practices there's no problem for any area. There never has been prehistorically-pre-contact time. Cultural practices were exceedingly careful about habitat."

"I mean, and it's our land-right? So we're not gonna do anything to have any, like we're not gonna just go in there and demolish it or stuff like that."

One interviewee stated that the Scientific Panel reserves were never meant to exclude First Nations from any part of the land base for their cultural use, and that those areas are just reserved from harvesting by licensees. However, government interviewees did feel that First Nations access to certain reserves for certain practices might be an issue. As one interviewee said:

"...there may be cases, ya, issues...the Ahousaht wanting access to reserves for traditional purposes. But... it would have to-I think because each reserve type is individually identified, and the reason for its existence is pretty clear, any traditional use proposal could be evaluated for consistency with reserve objectives. ... However, as I said if it's a reserve that was identified for ecosystem representation as an intact old-growth ecosystem-and the traditional use would involve-say harvesting of cedar, it would become questionable that that area would still qualify as an intact ecosystem. However, it would be different if it's in a terrain reserve, like an individual cedar tree may be able to be removed without impacting the terrain stability of that area. So, it depends on the case."

Several First Nations interviewees stated that they will worry about this issue if and when it arises, and are not concerned about it at the present time. However, it may be a good precaution to come up with decision rules for how it will be addressed, and include them in the watershed plans.

On the contrary, some First Nations feel that parks and SP reserves offer an extra layer of protection to their CSAs, and in that sense, this overlap issue can be seen as a facilitator rather than a challenge. This point of view is shown in the following quotes from a Hesquiaht interviewee:

"I'd have to say that a large majority of the areas that are important to Hesquiaht are already in a protected area. And that's just for the parks in general. You go to the scope of reserves-reserves in general-reserves for hydroriparian, reserves for-you know landslides, reserves for forest interior conditions, take all of that, it's about $53 \%$ of the area is in that. So then if you say, $53 \%$ of it is already in reserves or parks, and then, you know-you give us a map covering that, and then
say-OK-of the remainder of that, is there anything you know that you want in a reserve or a protected area? Odds are they're gonna be very small."

\section{Oral vs. written tradition}

Since the cultural values inventory is based on interviews, the accuracy of the information can be considered suspect from a western scientific worldview. Several interviews from the government sector were sceptical about the accuracy of cultural inventory information, as the following quote from a government interviewee shows:

"...one criticism a lot of people might make of that is that a lot of it was sort of anecdotal. You know like, well, my uncle used to tell me that he used to hunt in there, or I remember when I was six years old I saw this, and so, quite often your typical reaction is, ya-well, when I was six years old I remember...(laughing), you know-so you tend to be able to, you can be kind of cynical of some of that information-right? You know- ya-well, I don't quite remember things the way they were, or how many generations removed are we from this information?"

From a First Nations perspective, where oral history is the main method of passing down knowledge, there is no reason to suspect its accuracy any more than there is for ecological inventories that are collected "scientifically." As an Ahousaht interviewee said:

"The most valuable is our oral teaching. It's something that's never looked at as very significant, but that's how our children learn. That's how we learn, it's something we're able to rely on. Things, see if the old storiesthings end up being trends, and if you watch-I watch really closely and you'll see that there's things in the stories that are true, and it's one of the most important things in our lives is the oral history."

The fact that the CSAs are protected through watershed unit plans, which are based on maps, is in itself a challenge, because several First Nations interviewees mentioned that they are not familiar with using maps. As one interviewee from Tla-o-qui-aht said:

“...elders have a hard time reading maps. If you show them, they can't really understand. Myself too. I need to understand more what does it really mean. When they come and display the maps, there are like 10-many maps, all of the same area. They show different layers-it's confusing for us as a nation. We need to make sure people really understand."

\section{Sites with no physical evidence}

Sacred sites that are used for prayer, cleansing, or other spiritual uses, contain no physical evidence of their importance for that use. This creates challenges with respect to monitoring and compliance enforcement of CSA protection under the watershed plans. It is difficult to monitor impacts on such intangible values. First Nations interviewees said that the families that use these sites will be monitoring them through regular use, and they would likely report any impacts to their nation's resource 
managers. Funding should be provided for First Nations to set up and run monitoring programs, if the watershed plans are to be successfully implemented as a tool to protect CSAs from logging impacts.

The lack of physical evidence also makes ground-truthing even more important, as the CSA maps will be the only information available to site level operators. If the sites are inaccurately placed on the map, there is a chance they will be damaged. ${ }^{9}$ Some industry and government interviewees were concerned with ground-truthing of CSA inventory information. A few First Nations interviewees also raised this as a concern. An Ahousaht interviewee felt that there was a need to check the data that was collected in interviews on the ground, to make sure that areas are correctly mapped:

"We've never gone out and ground-proofed it...Like I mentioned earlier, there was no ground-truthing done to verify some of the higher end of the cultural stuffthat's internal-we've discussed that we need to consult with the interviewees about the requirement for groundtruthing-how do you ground truth-with them I guess"

\section{Funding}

Ground-truthing information provided by all interviewees, using site visits and GPS, is a time-consuming and expensive task. Thus far, adequate funding has not been provided to enable First Nations to carry it out. First Nations interviewees note that although over \$10 million has been spent on inventory work in Clayoquot since the Scientific Panel Recommendations were adopted, much of the inventory work recommended in Report 3 has yet to be completed. A Government interviewee suggested that if the cultural inventories had been prioritized by First Nations earlier in the planning process, when economic conditions were better and unlimited funds were available under FRBC, this problem could have been alleviated. ${ }^{10}$

However, the high turnover in people involved in the planning committees on the First Nations side means that First Nations currently involved (who were interviewed for this study), may not be aware of government's earlier efforts to implement the recommendations from Report 3. Thus, some First Nations interviewees believe that a disproportionate amount of money was spent on ecological inventories, and that their cultural inventory work is under-valued by government.

\section{Hereditary vs. elected government}

The duality of governance systems in First Nations communities, with the hereditary chiefs maintaining certain responsibilities, and the elected chief and council taking on other responsibilities, adds a level of complexity for licensees and government implementing agencies. It is often necessary to consult with and

\footnotetext{
${ }^{9}$ The liaison and First Nations crew members might be able to guard against this occurrence, but they are likely not aware of sacred sites of all members. ${ }^{10} \mathrm{An}$ MOF official confirmed that 10 million dollars was spent on the ecological and archaeological inventory work in the early implementation phase funded by Forest Renewal B.C (FRBC) (Greg Bach, personal communication August 2003). An MSRM official confirmed that the majority of their current budget for completing the watershed plans is allocated to completing the First Nations cultural areas mapping. \$220000 has been spent on this thus far (Rudi Mayser, personal communication August 2003). First Nations on the planning committees did not decide to undertake full traditional land use mapping until later in the process, at which point FRBC was no longer in place, and given the change in economic conditions in the forest sector, sufficient funding is now lacking for completion of First Nations cultural inventories for the watershed plans.
}

have approval from both systems of government. Sometimes the two governing entities may have different goals and different views on the level of industrial forestry activities that is desirable or acceptable.

\section{CSAs change over time}

Many First Nations interviewees stated that they do not feel that they will ever have collected all the CSA information for their territory. One reason is that uses are changing with time, and another is that people continue to come forward with additional information for the maps.

Several First Nations interviewees stated that the government and companies have not solicited or listened to their concerns for so long, that it will take time for people to realize that they can have some meaningful input. As people start to realize this, participation will slowly increase. As an Ahousaht interviewee said:

"I think the more that our people realize that they are being listened to, the more that will come back to them... We've been held back for so long that, sometimes we forget about all of the abilities that we have. And it's still there."

In an informal conversation with a hereditary Chief from Ahousaht, he touched on this further, in that First Nations people are still recovering from colonization. He emphasized that after so much oppression, things do not come back right away; it takes time.

This highlights the need for continued consultation. The existence of CSA maps does not preclude the need for consultation; rather, they should be seen as a tool to aid in consultation (Tobias 2000, Horvath et al. 2001). Industry and government must continue to consult directly with the community, in order for CSA maps to be effective.

\section{Interaction with treaty sector}

An issue that interacts closely with implementation of the Scientific Panel recommendations is the treaty process through which First Nations land claims are being resolved by negotiation with the provincial and federal governments. Although some First Nations interviewees claimed that they try to keep business separate from politics as much as possible, their involvement in the treaty process impinges to some degree on all their activities in the resource sector. Treaty negotiations can be seen as both a challenge and as a facilitator to the implementation of the recommendations, depending on what aspect one considers.

Treaty issues act as a challenge in that it takes up much of the time and energy of some of the most highly educated members of the small First Nations communities in Clayoquot Sound, which decreases the amount of time and energy the community can devote to dealing with issues such as comanagement of forest resources.

An interviewee from the MSRM explains the challenges that treaty issues create:

"I think for First Nations, I think the challenge has been to, with limited resources, to sustain over time both the treaty process and input in the Clayoquot watershed planning. So there has been competition for scarce resources in that regard...the continuing uncertainty around land claims I think plays into the planning pro- 
cess in terms of delaying products. ...Ya, I think in terms of efficiency and longer time frames that are required-that's been an ongoing challenge."

Some government and industry interviewees also feel that First Nations treaty concerns affect the process for protection of culturally significant areas. As interviewees from Interfor and the MOF said:

“...you're trying to get a blend of science panel and treaty. So you have to be careful when you look at these things is that, people tend to colour them with-well we have a huge treaty interest area here so let's make that whole thing culturally significant. So you can have the whole landscape become culturally sensitive-right?"

"But the other part about it is that the First Nations are really reluctant to put things down on a map as reserve or not reserve because they feel like, well, they're giving it away for good if they don't do it."

Therefore, the implementation of the Scientific Panel recommendations can not be analyzed in isolation from concurrent developments in the treaty process. This is also clear in the text of the draft watershed unit plans, which state in the preface that the plans "do not prejudge the positions that either government or First Nations may take in treaty negotiations" (Clayoquot Sound Technical Planning Committee 2002). The inclusion of this statement was very important for First Nations.

Treaty issues are also tied into the overlap of claimed territories between tribes. There are overlaps between the claimed traditional territories of the three nations. Specifically, Ahousaht's claimed territory overlaps with both Tla-o-qui-aht and Hesquiaht's claimed territories. Therefore, when a licensee proposes operations in an overlap area, it has to consult with both First Nations, which each has its own systems. There may also be associated difficulties with completing the watershed unit plans for areas where such overlap exists such as the Hesquiaht planning unit. Once treaty is resolved, these overlap issues should also be resolved.

Treaty issues can also be seen as a facilitator to protecting CSAs, in that the Interim Measures Agreement is part of the treaty process, and some interviewees from government and industry sectors said that the IMA provides the only legal support for implementation of the Scientific Panel recommendations.

\section{Facilitators}

\section{High degree of support from all sectors}

Interviewees from all sectors said that completing the CSA inventories was very important. The fact that all parties agree on the importance of completing this work, and recognize its value not just to the First Nations, but also to government and industry, makes it likely that sources of funding will be found to ensure its completion for the remaining watershed planning units.

\section{First Nations control over process and information}

Another facilitator, and one that helps to ease the challenge of confidentiality, is that government and industry do not require details from First Nations in their cultural layers. They do not require them to show what values are being protected where. Although industry and government would like more specific information, the First Nations are in control of the amount and type of information that is shared. This increases the level of comfort for members providing information for inventories.

\section{Conclusions}

The major findings for each research question are summarized as follows: The recommendations on protection of cultural areas have been implemented by all sectors and are at varying stages of progress. Government has provided funding for First Nations to start CSA mapping for parts of their territories, and each First Nation has taken a different approach to its cultural values mapping. Licensees have consulted extensively with First Nations regarding their cultural areas and have adjusted their planning and operations accordingly. The key impacts of implementing the recommendations have been an improvement in the effectiveness of the consultation process for all parties through the completion of the cultural layers, accompanied by improved protection of culturally sensitive areas for First Nations. The factors that challenge and facilitate implementation of the recommendations are summarized in Table 2.

The Clayoquot Sound case is a good example of the many challenges that can arise with cultural values mapping. Although the process was well done in that First Nations had control over the process, as well as the information and its distribution, many challenges relating to cultural and worldview differences persist (McGregor 2002).

However, the value of the CSA inventory and mapping work that First Nations are doing in Clayoquot Sound is unquestionable. All sectors see that it will significantly improve First Nations ability to efficiently and effectively respond to consultation requests, which will enable government and industry to better fulfill their fiduciary obligations (Horvath et. al. 2001).

As there were no watershed plans officially in place at the time of this study, one cannot make definitive conclusions regarding the success of CSA mapping in Clayoquot Sound. Once the plans are in place, further research would be useful to determine how the different systems each First Nation has developed for protection of their cultural areas through the watershed plans affects operations in their territories.

Regardless of the fate of the Scientific Panel watershed plans, both the process and products of CSA mapping will benefit First Nations in the long run, in terms of trust and relationship building between sectors, as well as improved resource information management tools for First Nations (Tobias 2000, Horvath et. al. 2001).

This study has shown that in Clayoquot Sound, there are many challenges to implementation of CSA maps, and comparatively few facilitators. The complexity of these factors helps to explain why the watershed plans are taking so long to complete.

It is important to note that Clayoquot Sound is not a representative case for forest management in British Columbia. The existence of the Interim Measures Agreement and the Scientific Panel recommendations, as well as the continuing high degree of public and ENGO attention to the area in the wake of the 1993 protests, means that both government and forest licensees must pay close attention to First Nations issues in the region. The degree of mutual commitment to the resolution of these issues is much higher in Clayoquot Sound than in the majority of the province. Thus, it is likely that in other regions there would be comparatively more challenges and comparatively fewer facilitators. 


\begin{tabular}{ll}
\hline Table 2. Summary of challenges and facilitators \\
\hline Challenges & Confidentiality \\
- Family ownership \\
- Worldview differences \\
- Access to overlapping parks and reserves, \\
- Funding constraints \\
- Lack of physical evidence for some sites \\
- Dual government system \\
- Written vs. oral traditions \\
- Land use changes over time \\
- Interactions with Treaty sector, conflict of interest/ over- \\
lapping territory claims \\
- High degree of support for CSA maps by all sectors \\
- First Nations have control of process and information \\
sharing \\
- Added Protection due to overlapping parks and \\
reserves \\
- Interactions with Treaty sector (support from IMA)
\end{tabular}

The Tla-o-qui-aht First Nation has recently issued notice to evict a licensee from practicing forestry in its traditional territory (Anon 2003). The Tla-o-qui-aht wanted some areas excluded from a particular cut block for protection of certain wildlife, medicinal plants and sacred values, but the licensee and the Ministry of Forests felt that these values were provided for in adjacent areas and through other reserves in the watershed plan. The issue has yet to be finally resolved. This is one example of how the challenge of overlap of CSAs and other Scientific Panel reserves may play out. This dispute shows that the implementation of the Scientific Panel recommendations has not been sufficient to satisfy all the region's First Nations that their cultural values are being protected.

Nonetheless, in Clayoquot Sound, First Nations have much more input to forest management on Crown lands than they do elsewhere in the province. However, as the B.C. treaty process proceeds, First Nations throughout the province are gaining more control over the management of forest resources in their traditional territories. Thus, it is important to understand the factors explained in this case study that can affect the success of protecting cultural values in managed forests through the useful tool of CSA mapping. This analysis will be invaluable both for the Clayoquot Sound case, and for British Columbia as a whole.

\section{Acknowledgements}

A heartfelt thank you to the Ahousaht, Hesquiaht, and Tla-o-qui-aht First Nations for welcoming us into their territories to conduct this research. Thanks to James Swan and Rod Sam of Ahousaht, and Craig Paskin and Mike Amrhein of the Central Region Board for helping to set up the interviews. Thanks to the Ministry of Forests, the Ministry of Sustainable Resources Management, Iisaak Forest Resources and International Forest Products for their participation in the project. A special thanks to all who participated in interviews. This study would not have been possible without your generous input of time and information. Thanks also to John Innes, Doug McArthur and anonymous peer reviewers for their input and guidance. Finally, we would like to gratefully acknowledge the Social Sciences and Humanities Research Council for supplying grant number 410-2000-1432 that paid for the travel and research costs of the study.

\section{References}

Anon. 2003. Interfor "evicted" by First Nation. The Daily News. Prince Rupert. July 28, 2003.

Babbie, E. 2001. The Practice of Social Research. Wadsworth Publishing, Belmont. 577 p.

Booth, A.L. 1998. Putting "forestry" and "community" into First Nations resource management. The Forestry Chronicle 74: 347-351.

Clayoquot Sound Scientific Panel. 1995a. Report 3: First Nations Perspectives relating to Forest Practices Standards in Clayoquot Sound. Cortex Consultants Inc., Victoria, BC. 74 p.

Clayoquot Sound Scientific Panel. 1995b. Report 5: Sustainable Ecosystem Management in Clayoquot Sound: Planning and Practices. Cortex Consultants Inc., Victoria, BC. 296 p.

Clayoquot Sound Technical Planning Committee. 2002. Flores Island Watershed Reserve Plan. Draft for Public Review. Tofino, BC, Central Region Board. 114 p.

Darling, C. 1994. In Search of Consensus. University of Victoria Institute for Dispute Resolution. Victoria. 54 p.

Erasmus, G. 1989. Chapter 8, A Native Viewpoint. In M. Hummel (ed.). Endangered Spaces. pp. 92-99. Key Porter Books Limited, Toronto.

Friends of Clayoquot Sound. 1998. Implementing the Scientific Panel: Three years and counting. FOCS, Tofino. $65 \mathrm{p}$.

Gardner, J. 2001. First Nations Cooperative Management of Protected Areas in British Columbia. Foundations and Tools. Vancouver, BC, Canadian Parks and Wilderness Society - BC Chapter and Ecotrust Canada. 48 p.

Horvath, S., L. McKinnon, M. Dickerson and M. Ross. 2001. The Impact of the Traditional Land Use and Occupancy Study on the Dene Tha' First Nation. University of Alberta, Edmonton, Sustainable Forest Management Network. $46 \mathrm{p}$.

Iisaak Forest Resources. 2002. Iisaak Forest Resources. Iisaak. Ucluelet, BC. $24 \mathrm{p}$.

McGregor, D. 2002. Indigenous knowledge in sustainable forest management: Community-based approaches achieve greater success. The Forestry Chronicle 78: 833-836.

Ministry of Forests. 1995. Government Adopts Clayoquot Scientific Report - Moves to Implementation. http://srmrpdwww.env.gov.bc.ca/ specialprojects/clayquot/archive/news/nr070695.htm. Accessed April 2002.

Ministry of Forests. 2000. Clayoquot Sound Land Use Decision. www.for.gov.bc.ca/vancouvr/district/SOUTHISL/Clayoquot/clayoquot sound.htm Accessed April 2002.

Muhr, T. 1997. Atlas/ ti Version 4.2. Scientific Software Development. Berlin.

Oakes, J., R. Riewe, K. Kinew and E. Maloney. 1998. Sacred Lands. Aboriginal Worldviews, Claims, and Conflicts. Canadian Circumpolar Institute and University of Manitoba, Manitoba.

Province of British Columbia and the Ha'wiih of the Tla-o-quiaht First Nations, the Ahousaht First Nation, the Hesquiaht First Nation, the Toquaht First Nation, and the Ucluelet First Nation. 1994. Interim Measures Agreement. Province of British Columbia. Victoria, BC.

Province of British Columbia and the Ha'wiih of the Tla-o-quiaht First Nations, the Ahousaht First Nation, the Hesquiaht First Nation, the Toquaht First Nation, and the Ucluelet First Nation. 1996. Clayoquot Sound Interim Measures Extension Agreement. Province of British Columbia. Victoria, BC.

Province of British Columbia and the Ha'wiih of the Tla-oqui-aht First Nations, the Ahousaht First Nation, the Hesquiaht First Nation, the Toquaht First Nation, and the Ucluelet First Nation. 2000. Clayoquot Sound Interim Measures Extension Agreement: A Bridge to Treaty. Province of British Columbia. Victoria, BC.

Spiro, H.N. 2003. An implementation analysis of the Clayoquot Sound Scientific Panel recommendations on First Nations perspectives. University of British Columbia, Vancouver. $160 \mathrm{p}$.

Strauss, A.L. 1987. Qualitative analysis for social scientists. Cambridge University Press, New York. 319 p. 
Tobias, T.N. 2000. Chief Kerry's Moose: a guidebook to land use and occupancy mapping, research design and data collection. Union of BC Indian Chiefs and Ecotrust Canada, Vancouver. $65 \mathrm{p}$.
Toupal, R.S., M.N. Zedeno, R.W. Stoffle and P. Barabe. 2001. Cultural landscapes and ethnographic cartographies: Scandinavian-American and American Indian knowledge of the land. Environmental Science and Policy 4: 171-184. 